\title{
Invisibility, Inequality and the Dialectics of the Real in the Digital Age
}

\author{
Matteo Stocchetti \\ Arcada University of Applied Science, Helsinki - Finland - matteo.stocchetti@arcada.fi
}

\begin{abstract}
In the digital age, the practical possibility of

In line with the critical perspective of Anengaging inequalities as political problems, that is, as problems related to the competition for the control over the distribution of values in society, is undermined by the digital invisibility of reality

In the current state of affairs, the digitalization of society reflects the influence of capitalist interpellation and brings about the invisibility of the real. The invisibility of the real through capitalist digitalization, in turn, conflates digitization and digitalization subordinating the latter to the former. Construed as a process inspired by technological rationality, capitalist digitalization undermines the possibility of mobilizing knowledge and legitimizing practices in support of the interpretation of invisibilities in relation to inequalities drew Feenberg and others, my approach is that the influence of capitalism in the digital age results from an epistemic appropriation of a technological development. This appropriation is the source of invisibilities that support inequalities and ultimately injustices that can and should be opposed. Leading on from this, my point is that opposition to this influence depends on the possibility of establishing alternative epistemic grounds and the formulation of alternative interpellations for the production of digital subjectivity.

To foster the normative agenda of critical theory, I discuss this possibility in terms of the 'dialectics of the real', the re-politicization of the social construction of reality in the digital age and the role of critical media literacy.
\end{abstract} and injustice.

Keywords: Interpellation, digitization, digitalization, dialectics of the real, social construction of reality, capitalism

\section{Invisibilidade, Desigualdade e Dialética do Real na Era Digital}

\section{Resumo}

$\mathrm{Na}$ era digital, a possibilidade prática de engajar desigualdades como problemas políticos, ou seja, como problemas relacionados com a competição pelo controle da distribuição de valores na sociedade, é prejudicada pela invisibilidade digital da realidade. 
No atual estado de coisas, a digitalização da sociedade reflete a influência da interpelação capitalista e provoca a invisibilidade do real. A invisibilidade do real através da digitalização capitalista, por sua vez, confunde digitação e digitalização, subordinando esta última à primeira. Construída como um processo inspirado na racionalidade tecnológica, a digitalização capitalista compromete a possibilidade de mobilizar conhecimentos e legitimar práticas de apoio à interpretação das invisibilidades em relação a desigualdades e injustiças.

De acordo com a perspectiva crítica de Andrew Feenberg e outros, a minha abordagem é que a influência do capitalismo na era digital resulta de uma apropriação epistémica de um desenvolvimento tecnológico. Esta apropriação é a fonte de invisibilidades que apoiam desigualdades e, por fim, injustiças que podem e devem ser combatidas. Partindo disso, o meu ponto é que a oposição a essa influência depende da possibilidade de estabelecer fundamentos epistémicos alternativos e da formulação de interpelações alternativas para a produção da subjetividade digital.

Para promover a agenda normativa da teoria crítica, discuto essa possibilidade em termos da 'dialética do real', da repolitização da construção social da realidade na era digital e do papel da literacia mediática crítica.

Palavras-chave: Interpelação, digitação, digitalização, dialética do real, construção social da realidade, capitalismo

\section{INTRODUCTION}

The main point of this paper is that the capitalist appropriation of digital affordances produces invisibilities, and in particular the 'invisibility of the real', whose fundamental effect is to preserve the hegemony of capitalism in the present and to project it into the future. In order to resist this hegemony and re-appropriate the emancipative potential of digital technology, it is important to re-establish the visibility of the real and the political dimension of the social construction of the real. In other words, we need to restore the possibility of thinking about technological development, relations of power, social change and the future outside the influence of capitalist ideology.

My starting point is that communication, visibility and inequalities are connected and that every form of communication reveals something and hides something else. This connection thus establishes different patterns of the visibility and invisibility of equalities and inequalities: different codes, rules, routines, conventions, practices that 
ultimately determine which difference is relevant and which is not, which one can or cannot be ignored.

The concept of (in)visibility here is taken in its broader meaning or semantic connotation, which includes the ideas of attention or prominence and of awareness or knowledge.

The concept of inequality combines 'difference' with 'power' or, more precisely, the distribution of differences with the distribution (or hierarchy) of power. The association between inequalities and injustice is based on implicit ideas concerning the distribution of differences, the distribution of power and the (il)legitimacy of the association between the two.

These definitions/distinctions are important because in every society only some differences have the social significance of inequalities and only some inequalities are construed as injustice. What differences are treated as injustice and how ultimately depends on ideological interpellation. This notion was originally coined by Louis Althusser to discuss how capitalist ideology manipulates people into compliance with what is ultimately a system of production based on exploitation. For Althusser, ideology works by interpellating individuals as subjects (1971/2008, pp. 44-51) and the subjects so constituted by ideological interpellation make ideology possible. This process of 'double constitution' may seem quite implausible and difficult to understand unless one considers that, according to Althusser:

Ideology is a 'representation' of the imaginary relationship of individuals to their real conditions of existence (p. 36) (My italic).

For our discussion, this interpretation of ideology and interpellation has at least two implications, on analytical and epistemic grounds. First, the role of communication technology in society is subordinated to that of ideology and of the ideological role of other institutions in society. In a critical perspective, it is important to point out that patterns of (in)visibility and (in)equality are not 'caused' by some intrinsic qualities of communication technology. As Andrew Feenberg convincingly argues in his description of a critical theory of technology, technology alone is not responsible for the effects of technology on the distribution of power or inequalities in society. According to Feenberg,

technologies are not separate from society but are adapted to specific social and political systems. Technologies are thus not neutral tools, because they are implicated in the socio-political order they serve and contribute to shaping, nor 


\section{Invisibility, Inequality and the Dialectics of the Real in the Digital Age}

can they be characterized by a singular "essence of technology" because they evolve historically along with other aspects of society. Just as institutions, laws and customs can be changed by human action, so can technological systems. (Feenberg, 2009, p. 146)

If the socio-political order served by the information revolution and digitalization is that of Western, post-industrial, 'mature' or global capitalism, as has been argued at least since the 1980s (Schiller, 1980; Inayatullah, 1998), the question to ask is then not what does digital technology do but how does capitalist technological discourse legitimizes patterns of (in)visibility and (in)equality that contribute to the legitimization of capitalist socio-political order (Fisher, 2010): what is revealed, what is hidden, and how invisibilities relate to injustice?

Second, since 'ideology represents the imaginary relationship of individuals to their real conditions of existence' (Althusser, 1971/2008, p. 36), the role of communication technology becomes crucial: well beyond the mere communication of information and, more fundamentally, in the production of the (ideological) representation of reality. In this perspective, one can appreciate the distinctive feature of the digital age. As I argue in the rest of this paper, the patterns of (in)visibility, (in) equality and (in)justice associated with the digital age are unique to the extent that they involve what I summarize as 'the invisibility of the real'.

\section{DIGITAL INVISIBILITIES}

Patterns of (in)visibility and (in)equalities can be described in relation to at least three main dimensions: the individual, social and epistemic dimensions. To anticipate the main points of my argument, the distinctive, and in some respects more disturbing, aspects of the digital age pertain to the epistemic dimension, or the invisibility of the real'. This aspect, which concerns the possibility and accessibility of shared truths, has crucial political implications: the invisibility of the real dissolves the possibility of linking inequality with injustice, preserving both but undermining collective action against the conditions through which the former produces the latter. To address this problem, in the concluding section I describe an epistemic standpoint I call 'the dialectics of the real'. Before that, however, I discuss 'digital invisibilities' from the individual, social and epistemic dimensions. 


\section{The individual dimension}

Quite intuitively, the digital age makes invisible those people who do not have access to digital technology or who have access to it but not the material and immaterial resources (e.g. skills, time, money, etc.) to compete for visibility with the new digital elites (van DijK, 2012). The relevant debate here is the one about the 'digital divide' and relevant inequalities associated with this divide (see e.g. (Rooksby \& Weckert, 2007)).

Perhaps less intuitively, however, the digital age is associated with important invisibilities in the production of subjectivity: a process increasingly dependent on a technological infrastructure almost completely owned by corporations and instrumental to their interests. The mediated production of subjectivity reveals the influence of the social in the constitution of the self but hides the role of corporate ideology and norms in the process.

Discussing the alleged affordances of digital technology in enabling the formation of subjectivities, for example, Rob Cover (2016) argues that the nature or direction of these affordances is fundamentally influenced by 'the encroachment of a neoliberal commodification of digital activities' (p. xix). As a result,

the contemporary subject of digital media may be one who is engaged forcefully in interactive behavior, innovative creativity, sharing, and participation, but the basic requirement to participate is to be a subject who conforms vehemently to an individualized stylization of performativity. (p. 264)

In his research on social media, Christian Fuchs has exposed 'the double logic of commodification and ideology that shapes corporate social media' which, behind the 'social', hides 'capital accumulation... based on user data commodification, the unpaid labour of Internet users, targeted advertising and economic surveillance' (Fuchs, 2014, p. 342).

Discussing the role of digital technology in the key domain of education, Karen A. Ferneding argues that technocentric discourse in education technology supports the influence of neoliberalism in education while marginalizing issues of social justice and alternative visions of social order (Ferneding, 2003).

In the conditions of the digital age, therefore, the production of subjectivities through mediated communication, e.g. in education, social media, etc. depends on a preliminary and necessary compliance with rules ultimately established to serve corporate interests and ideology. 
The relevant invisibility here is not that of people or inequalities but the invisibility of the influence of the digital infrastructure and ideological interpellation in the formation of (digital) subjectivities. What remains hidden here is the fundamental fact that the social production of the self in the digital age is influenced by a communicative infrastructure that interpellates its users as ideological subjects (e.g. 'prosumers') and, to recall Althusser, reproduces capitalism as the dominant 'representation of the imaginary relationship of individuals to their real conditions of existence' (supra).

This representation is obviously manipulative since, for example, it formally endorses the centrality of the individual and the production of autonomous subjectivities but hides the conformist influences of digital socialization and detrimental effects such as digital addiction, isolation, etc. especially among younger generations. Similarly, while it establishes the hybrid social character of the 'prosumer', it hides the decline of the citizen.

\section{The social dimension}

From the perspective of interpellation, the most interesting aspect of digitalization is the intrinsic ambivalence of the patterns of social visibility and invisibility. In the digital age, the communicative production of the social is a process that feeds very opposite representations of the 'imaginary relationship between the individual and its conditions of existence?

On the one hand, the emphasis on information, information flows and the network support the 'computopia' (Masuda, 1981) of the 'information society', a state of affairs characterized, among other things, by 'freedom of decisions' and 'equality of opportunities', and, more broadly, one in which class differences, inequalities, struggle and exploitation have disappeared as a result of mere technological progress. On the other hand, the same technological infrastructure generates phenomena such as 'filter bubbles' (Pariser, 2011) and 'eco chambers' (Flaxman, et al., 2016) whose function is to give expression to voices of more or less radical dissent against the sociopolitical order served by the digital utopia.

The remarkable aspect is that the repression of social conflict feeds the radicalization but also the digital isolation of dissidence in a vicious circle that ultimately disrupts the social production of the social. 
The disruptive potential of this ambivalence in the production of the social is not a recent discovery. Since the early stage of the information revolution, for example, scholars have warned against the risk of the emphasis on information and its delivery side-lining or neglecting issues of equitable distribution of the benefits associated with the development of information systems (Machlup, 1962; Machlup, 1980-84).

Early critics of the information society expressed their scepticism and argued that capitalist interests are bound to prevail because the political economy of the information society was, and still is, in corporate hands (Schiller, 1981) and fundamentally subservient to corporate ideology (Shiller, 1999).

More recently, and following Roland Barthes (Barthes, 1957/2000), Vincent Mosco, argued that the myth of cyberspace is a form of 'depoliticized speech' that can 'purify social relations by eliminating the tensions and conflicts that animate the political life of a community' (Mosco, 2004, p. 31). In particular, the myth of the Information Age denies history and 'transcends politics because it makes power available to everyone and in great abundance. The defining characteristic of politics, the struggle over the scarce resource of power, is eliminated. In this respect, myths create a new history, a new time, by denying history (Mosco, 2004, p. 35).

Discussing the risks related to the current stage in the evolution of the information society, Alistair S. Duff (2012) argues that it is necessary to acknowledge and to address 'the normative crisis of the information society' (p. 7) and to raise the problem of 'information inequality's significance' (p. 14).

For the purposes of our discussion, the contributions of these and other authors give grounds to the idea that the patterns of visibility and invisibility related to the production of the real in the digital age have fundamentally ambivalent effects. While enforcing representations of the social imaginary that support the computational utopia on the one hand, they incite or feed the radicalization but also the isolation of dissidence on the other.

On more political grounds, this state of affairs has at least two implications worth mentioning. First, the social produced by this pattern of visibility/invisibility is an ambivalent creature: the routine announcement of 'revolutionary' change, hides continuity in the structure of power and inequalities; the celebration of ICT democratic potential is an incitation to forget the fact that technology alone cannot change relations of power (Lyon, 1986); the emphasis on digital 'enabling potential' hides growing socioeconomic inequalities, the growing role and influence of surveillance and the erosion of individual privacy by both state and corporate actors (Allmer, 2015) (Fuchs, 2014). In 
other words, this is a social in which the focus on the 'power' of connectivity marginalizes formidable problems concerning the grounds of legitimation of this power, hence blurring the distinction between its legitimate and illegitimate uses.

Second, these ambivalent patterns of visibility/invisibility in the digital production of the social, have implications for social change. For all practical purposes, this ambivalence protects the capitalist social order from dissidence but undermines the legitimization of democratic political regimes by facilitating the repression and isolation of dissidence in forms and content (organizations, rhetorics, propaganda, activism, protest, etc.) too often incompatible with the form and content of democratic politics. In other words, online activism does not undermine capitalist interpellation, but seems an excellent breeding ground for radical ideas and movements excluded from more traditional institutions (media, parliaments, political parties, etc.) of democratic regimes.

It is important to keep in mind that these patterns of visibility/invisibility, and the disruptive communicative effects on the democratic regimes, are not intrinsic to ICT but result from the process of interpellation I described above: the specific 'representation of the imaginary relationship of individuals to their real conditions of existence' associated with 'the free market' utopia.

The most distinctive of the invisibilities of the digital age, however, is the invisibility of the real'.

\section{The epistemic dimension: the invisibility of the real}

In philosophical discourse, the 'real' describes what is true, authentic and which, therefore, constitutes 'reality' as the ground for the possibility of truth, knowledge and justice, communication and organized, collective action. If we take visibility to mean attention or prominence, awareness or knowledge, to argue for the invisibility of real in the digital age means to suggest that some identifiable set of conditions commonly referred to as the 'digital age' contributes to make this common ground both less accessible and less relevant.

Here I would like to suggest that this 'invisibility of the real' is the outcome of an ideological appropriation of the two fundamental 'turns' I have discussed more at length elsewhere: the epistemic turn of social constructionism in the 1960s and the 'digital turn' in ICT at around the turn of the millennium (Stocchetti, 2017). 
The ideological appropriation of an epistemic formulation is in essence a hermeneutic process by which the purposes of the formulation are separated from its conceptual tools and substituted with other purposes. This possibility exists because, put simply, despite the fact that truth and justice are values equally relevant in epistemic practices, the ways in which we learn what is true or false are different from the ways in which we establish what is right or wrong. The appropriation of the constructivist 'turn' by capitalist ideology was motivated by the fact that the new epistemic brought about the politicization of the real, and the ensuing consideration that, if reality was socially constructed especially through communicative practices, the control of reality was a possibility based on the control of these practices (Stocchetti, 2017). In other words, the emancipative purposes inspiring the idea that 'reality is what we make of it' were substituted with the purpose of preserving capitalism by 'making reality what we need of it'.

The ideological appropriation of the affordances of the 'digital turn' was brought about through the conceptual confusion between the double process of digitization and digitalization, and by the subordination of the latter to the former. Digitization is a process of representation through binary codification and de-codification of the sensorial aspects of the social world. Digitalization is the process describing the social changes associated with digitization. But while digitization is a process associated with and in relevant measure controlled by the social forces involved in technological development, digitalization is a process of social change involving a wider range of forces, interests, values, visions, etc. Most importantly, digitalization involves normative questions (Duff, 2012).

Thus, the ideological appropriation of the 'digital turn' occurred through the confusion between these two processes and the subversion of the relation between them: putting the development of digital tool, or digitization, before the development of (digital) ends, or digitalization. Once digitization (a technological or instrumental process) is confused with digitalization (a social process), and the latter is subordinated to the former, the process of social change is confined within the narrow terms of technocentrism and, ultimately, inscribed within the ideological project of neoliberal globalization.

For all its simplicity, the slogan 'the virtual is the new real' effectively expresses the basic idea that the source of social change has moved from the 'old' to the 'new' real: from the domain of politics and the competition for the control over the distribution of values in society, to the domain of technological development, network management and digital surveillance. This slogan and its broad popular acceptance 
are perhaps the most convincing evidence that the apprehensions voiced by at least three generations of critical scholars, from Herbert Marcuse to Jean Baudrillard and Andrew Feenberg, are not unfounded.

\section{DIGITIZATION AND ITS SUBVERSION: THE POLITICS OF THE REAL}

The invisibility of the real is an epistemic move with political consequences. It is a move made possible by epistemic and technological innovations and by the relative positioning of social forces in condition to take advantage of them while others could not.

The idea that reality is socially constructed establishes reality as a stake in a political competition. To the extent that the construction of reality depends on communicative practices, it also makes the control of communication technology a strategic resource.

As James Carey noted:

Reality is, above all, a scarce resource. Like any scarce resource it is there to be struggled over, allocated to various purposes and projects, endowed with given meanings and potential, spent and conserved, rationalized and distributed. The fundamental form of power is the power to define, allocate, and display this resource. Once the blank canvas of the world is portrayed and featured, it is also pre-empted and restricted. Therefore, the site where artists paint, writers write, speakers speak, film makers film, broadcasters broadcast is simultaneously the site of social conflict over the real. It is not a conflict over ideas as disembodied forces. It is not a conflict over technology. It is not a conflict over social relations. It is a conflict over the simultaneous codetermination of ideas, technique, and social relations. It is above all a conflict not over the effects of communication but of the acts and practices that are themselves the effects. (Carey, 1988, p. 87)

In this competition, the digital infrastructure is a formidable resource for those who can control it. It not only increases the speed and quantity of information about reality but, in order to do so, it requires and fosters the transformation of reality itself. The digitization of reality does not merely represent reality: it creates a new 
reality that, by definition, is completely under the control of its infrastructure. In this new reality, the production of knowledge combines with the legitimization of power through what Jean-François Lyotard called 'performativity' or 'the best possible input/output equation' (Lyotard, 1979/1982, p. 48) and facilitates the achievement of goals by making them 'invisible' or beyond the reach of critical evaluation.

Because digitization is so effectively instrumental, digitalization, or the adaptation of the social world (practices, institutions, relationships, etc.) to the requirements of digitization, seems inevitable. This inevitability is expressed by a variety of slogans that, while reflecting, promoting and rejuvenating technological myths, are endorsed with the socio-political influence of actors that more or less consciously seek to gain control of the communicative construction of reality.

The invisibilities associated with this move support new structures of inequalities, illegitimate distribution of power and, therefore, injustice. From a critical perspective, however, the fundamental task is not to list these invisibilities but to look deeper into the invisibility of the real: to understand the nature of this process, the conditions that make it possible, the possible implications in terms of power and legitimacy, the nature of the risks, challenges and opportunities associated with them and, in line with the normative ambitions of critical theory, to delineate plausible interventions to resist oppressive consequences and support the opportunities for emancipation.

Once the social world is re-constructed within a reality fully inscribed within the instrumental logic of digitization, rejection of digital technology is not an option. This is so not only because technological innovations, once they exit the laboratory and blend with society, become a constitutive part of society itself. As the critical theory of technology illustrates, technology is neither neutral nor equipped with ideological preferences on its own. The problem does not reside primarily in the tools or technology per se, but in the influence of the capitalist ideology that makes efficiency a paramount value and discounts, neglects and excludes the social costs of capitalist development and, most dramatically, the possibility that the future of society may perhaps be inspired by visions other than the free-market utopia (Polanyi, 1944/2001), p. 3).

An alternative strategy is that suggested by Andrew Feenberg which he describes in terms of 'subversive rationalization' (Feenberg, 1992):

Constructivist and hermeneutic approaches to technology show that modern societies are inherently available for a different type of development in a different cultural framework. It is possible that, in the future, those who today are 


\section{Invisibility, Inequality and the Dialectics of the Real in the Digital Age}

subordinated to technology's rhythms and demands will be able to control it and to determine its evolution. I call the process of creating such a society 'subversive rationalization' because it requires technological advances that can only be made in opposition to the dominant hegemony. (Feenberg, 1992, p. 301)

Echoing the apprehension of the Frankfurt scholars (Horkheimer \& Adorno, 1969/2002; Horkheimer, 1947/2004; Marcuse, 1941/1998; Marcuse, 1964/2002), Feenberg exposes the beliefs 'that technical necessity dictates the path of development, and that the pursuit of efficiency provides a basis for identifying that path' as false beliefs or 'ideologies employed to justify restrictions on opportunities to participate in the institutions of industrial society'. Conversely, he believes that 'we can achieve a new type of technological society which can support a broader range of values. Democracy is one of the chief values a redesigned industrialism could better serve' (Feenberg, 1992, p. 318).

The problem, however, is that even wrong beliefs can be influential and produce consequences affecting the competition for the control of the construction of reality. Discussing knowledge and temporality, for example, Robert Hassan (2003) argued that in the digital age, the time of the network has substituted real time with the consequences of subordinating reflexive and evaluative knowledge to the instrumentalized knowledge' of the 'competitive market environment' (p. 238). The regime of the 'time of the network' is established by 'the nexus between neoliberal globalization and the ICT revolution' (p. 239).

$[D]$ igital structures permeate the economy, culture and society to a degree that is historically unsurpassed, creating in the process a distinct 'information ecology'. (...) In this accelerated ecology, the creation and application of reflexive knowledge and reflexive evaluation becomes increasingly difficult. There is simply less time for it - and less perceived need for it in an increasingly competitive and profit-driven social-economic system. (...) When people are the weakest link' in this chrono-digital ecology of our own making, then one of the central ironies of the information age becomes apparent. In the name of 'efficiency', neoliberalism has abrogated social control to both 'market forces' and computer networks of automation. Even those 'in control', those in the boardrooms and cabinet offices of the great and powerful are essentially 'out of control' as their 'timeframes for action' are set in the present or the near future, 
with the consequences of their actions (...) spiraling out into an unknown eternity. We have less time to think about the future because a 'competitive market environment' compels us to think 'fast' and apply instrumentalized knowledge to the here and now. (Hassan, 2003, pp. 237-238)

In this interpretation, the digital manipulation of time affects not only the 'speed' of people's life but also the production of knowledge, prioritizing instrumental or performative knowledge over evaluative, reflexive or critical knowledge. The subordination of real time to the time of the network is associated with the subordination of knowledge to the needs of the 'information ecology' that generates and supports the network.

Questioning the role of technology, however, Feenberg claimed that democracy has 'not been extended to technically mediated domains of social life despite a century of struggle' not because 'technology excludes democracy' but 'because it has been used to block it' (Feenberg, 1992, p. 320). But if technology has been used to block democracy, how can we 'redesign industrialism' so that the same technology can serve democracy? The idea of a 'redesigned industrialism' that could serve democracy describes a desirable goal but falls short of suggesting suitable means or ways to get there.

As I have suggested here, digital technology could 'block democracy' because influential forces managed to take advantage of its epistemic affordances to nullify a century of struggle' and take control of the communicative construction of reality.

In this perspective, the invisibility of the real is a problem with an epistemic dimension that requires an epistemic solution: one that would allow the supporters of democracy to engage their enemy in the new reality. What is needed, in other words, is a conceptualization of the real that helps in addressing not only the invisibilities of the digital age but also the ideological roots of these invisibilities. Interpellation is one of the concepts I suggest could be usefully part of a critical framework and, with it, the idea that the mainstream uses of technology, e.g. in the production of subjectivities or in the re-production of society, interpellate subjects in forms that 'make ideology possible': that actualize the neoliberal project into daily communicative practices.

A more radical proposal involves re-conceptualizing the social construction of reality in terms of a process with competitive and cooperative aspects or, more technically, in terms of the dialectics of the real. 


\section{THE RE-POLITICIZATION OF THE DIGITAL AGE AND THE DIALECTICS OF THE REAL}

As I argued in the beginning, in order for inequalities to be interpreted as injustice, it is necessary to think of difference in relation to the distribution and legitimation of power. Inequalities conceived independently from power and legitimation are merely differences. The problem with the double process of digitization/digitalization resides precisely in this decoupling.

The invisibility of reality can be interpreted in epistemic terms as a condition in which the possibility of common ground in support of truth claims is both less accessible and less relevant. This epistemic condition has political consequences: consequences that affect the competition for the control over the distribution of values in society. The fundamental aspect of these consequences is that the invisibility of the real supports the hegemonic structure of power by avoiding the problematization of inequalities in terms of knowledge and relations of power. In other words, the invisibility of the real inhibits the politicization of inequalities, that is, the problematization of differences in terms of its relation with (il)legitimate power.

From a critical perspective, the intellectual response to this condition requires an alternative engagement with reality or, more precisely, with the epistemic foundations of this notion.

Reality is the ground on which truth claims of some sort are possible. Without the possibility of truth, political behaviour is deprived of its moral dimension and communication is reduced to what Jürgen Habermas called 'strategic communication'. The role of reality undergoes a fundamental change: from common ground for the articulation of truth claims in support of moral claims and the legitimization of political action, to the self-legitimizing outcome of a form of communication in which the only goal is not the construction of truth but the augmentation of power. This is what Jean-François Lyotard called 'performativity' (Lyotard, 1979/1982, p. 48).

The patterns of visibility/invisibility associated with the individual, social and epistemic dimensions of the digital age support patterns of inequality that are construed as differences rather than injustices because they are legitimized by the double process of digitization/digitalization and by the ideological interpellation of the subjects and the relations that constitute them.

The construction of subjectivities in a digital environment under corporate control, for example, supports a fundamental informational imbalance between the in- 
dividual on the one hand, and the state and the corporation on the other. The information society' that emerges from this imbalance is a two-strata society in which the power of digital elites over the digital masses is legitimized not in relation to the uses of this power, its social goals and effects, but in relation to an unquestioned and seemingly inevitable digital future and market economy. The slogan 'program or be programmed' (Rushkoff, 2010) expresses, perhaps provocatively, the idea of a radical polarization of political power, but it also points to its main source of legitimization: the control over digitization.

Thus, the main implication of the invisibility of the real is the political invisibility of structural injustice: the decline in accessibility and relevance of the conditions and tensions through which the production of knowledge legitimizes differences while hiding illegitimate inequalities.

In this perspective, the possibility of resistance to the ideological invisibility of structural injustice in the digital age does not reside in the rejection of the digital but in the preliminary re-constitution of the real or, more precisely, of its epistemological grounds, so to make these conditions and tensions in the production of knowledge and legitimation newly relevant and accessible. In practice, we need a formulation of the relationship between knowledge, truth and power capable of antagonizing the influence of capitalist interpellation in the digital age (Stocchetti, 2017).

In the technological discourse of capitalist interpellation, the construction of reality is no longer a social or political process but a techno-administrative one. The digital age, in its current stage, rather than the 'global village', seems more likely to bring about global surveillance. This outcome, however, is far from inevitable and there is at least discursive evidence that the legitimization of this transformation is problematic. The slogan, 'the virtual is the new real', for example, is an ideological incitation similar to that 'the king is dead, long live the king!' It seeks legitimization through continuity: the legitimization of the 'new real' by representing the transition from the 'old real' as a natural transition. Like all ideological slogans, also this one hides its ideological function: the legitimation of the virtual as the new real since, in fact, the 'virtual' is not the 'real'. It also hides the fact that this transition is far from a 'natural' process but very much a political one: a process in which material and immaterial resources are used by identifiable actors in the competition for control of the social construction of reality.

If, as Feenberg suggested, we need to redirect the role of technology from blocking democracy to supporting it, we need a ground to resist the effects of capital- 
ist interpellation in the digital age. We need to re-deploy the construction of reality on epistemological grounds in ways that can help the recovery of the emancipative potential of the idea that 'reality is what we make of it'. A proper discussion of the epistemological features of such grounds would require an engagement with critical realism and social constructionism that is not possible here. Within the limits of this paper, I will thus confine myself to the problem of digital invisibilities and the influence of capitalist interpellation on the social production of reality in the digital age.

The main idea of this approach is that what we usually call reality is an impermanent result of a complex and multidimensional process through which people, groups and institutions manage to give a temporary solution to opposing tensions. This process contains competitive and non-competitive aspects and is based on communicative and non-communicative practices. The same process, however, has a political dimension to the extent that the specific solutions to opposing tensions have implications for the competition for control of the distribution of values in society or, as Harold D. Lasswell puts it, the question of 'who gets what, when and how' (Lasswell, 1936/1950).

The awareness that the construction of reality is a dialectical process with a political dimension and political consequences is the first step for the re-politicization of the real. This process stands, so to say, on two legs: first, the rejection of capitalist interpellation and influence on the digitalization of society; and, second, the production of ideological formulations capable of expressing alternative technological interpellation in support of more emancipative representations of the imaginary relationship of individuals to their real conditions of existence.'

The idea that reality is the impermanent result of dialectical tensions has two implications. First, it makes visible the influence of non-hegemonic social forces and ideologies, thus opening the possibility of political mobilization and anti-hegemonic coalition at both levels of policies and politics. Second, it performs descriptive and prescriptive functions: it tells something about how this process works and what its participants should keep in mind if they want to be influential. Behind this idea and these two implications is the fact that the social construction of reality does not take place in a vacuum but in a social environment populated by a rich variety of relations, ideas, visions, histories, hidden and overt conflicts, regularities, paradoxes, etc. The interpretation of reality as the result of a linear or even incremental process performed by 'structures' in a politically or ideologically neutral environment (e.g. the digital environment) is itself an ideological artefact to hide, naturalize and legitimize the influence of a hegemonic ideology in the social construction of reality. 
The dialectics of the real involve a complex interplay of the material and immaterial dimensions. One important step to counter the influence of capitalist digitalization is to re-evaluate the material dimension of political power and to consider the possibility that ideological manipulation may be accountable for overrating the subversive potential of the digital. As I argued elsewhere, in relation to the role of digital visuality (Stocchetti, 2014), the effective exercise of political power requires solid connections to the material dimension of political struggle. More generally, the emphasis on the 'subversive potential' of digital communication may make people forget that the legal systems of democratic regimes still offer powerful tools to address and inhibit the transformation of (digital) invisibility into (digital) inequality and (digital) injustice. The approach of critical political economy of the media (Hardy, 2014) is most useful to engage with the material grounds of capitalist interpellation of digitalization and the possibility of reducing corporate control of the digital infrastructure. We should however keep in mind that the legal system and political economy are also arenas of political struggle: places of institutional confrontation between social forces associated with or antagonistic of the capitalist control of digitalization. The role of the institutional dimensions and of institutions as both tools or resources and arenas of political struggle is also an influential dimension of the dialectics of the real whose importance should not be overshadowed, for example, by the alleged influence of online activism.

The political relevance of online activism, and its limits, are defined by the extent this form of communication can (or cannot!) influence and support or undermine the possibility of successful redistribution of power in society. The digitalization of political activism both aggregates and isolates political dissidence, creating communicative micro-cosmos in the form of eco-chambers or filter-bubbles with problematic effects on the capacity of democratic regimes to handle social change. These micro-cosmos facilitate the survival of groups and political movements too radical to get enough acknowledgment offline, and are instrumental to the control of resources that may eventually support activism offline. The construction of an ideological and more democratic alternative to the capitalist digital interpellation requires a critical reflection on the relative advantages and disadvantages of digital activism. To the extent that democracy flourishes on the confrontation of different opinions, for example, it is important to understand if and when the internet can facilitate or hamper democratic communication and the formation of democratic 
subjectivities (see e.g., Dahlberg, 2011). Taking this argument further, we may even question the suitability of online activism where the goals are to foster awareness of the detrimental effects of digital isolation on democratic politics.

\section{SUBVERSIVE RATIONALIZATION AND CRITICAL MEDIA LITERACY}

The points I have discussed in this paper are compatible with and inspired by, among other sources, Feenberg's idea that 'the dominant model of industrial society is politically contingent', and by his appeal to 'subversive rationalization' (Feenberg, 1992, p. 301). In this concluding section, I would like to go one step further and suggest how professional educators may contribute to 'subversive rationalization' in media education.

The capitalist appropriation of the 'digital turn' in education, far from being a 'revolution', consists mostly of a change in which educational and pedagogical content and relations are re-inscribed within the limits or 'affordances' of new technologies and, what is most disturbing, of an inescapable 'digital future'. Digital capitalism seeks to preserve itself by taking root in education, by establishing a 'digital pedagogy' that could form individuals compliant with the invisibilities of the digital age and the injustices associated with it, in the same ways as we are accustomed to the differences and injustices that the natural world and luck, or lack of thereof, impose on us. In the past decade or so, these efforts have been met with growing resistance, and the increasing influence of critical studies in education, pedagogy and technology testify that the efforts to preserve the grip on capitalist interpellation on technological development are met with resistance.

If reality is construed as an impermanent outcome of dialectical tensions, we need to appreciate the ideological and socio-political role of education. This role cannot be overestimated, and the influence of capitalist interpellation on the digitalization of education reveals the fundamental importance of this institution in the re-production of reality. The idea that reality is the result of the temporary resolution of dialectical tensions may support a critical epistemology but remains quite sterile on ideological grounds if democratic education fails to give people the means and the will to participate in the construction of reality, that is, to reclaim the sovereignty expropriated by the capitalist interpellation. Put simply, we need individuals who are able to take advantage of whatever opportunities these critical epistemological 
grounds may offer in support of the re-politicization of the real. How to form this kind of individuals is a problem that has to do with pedagogy, or the formation of individuals, more than with education and professional training, if these two activities are interpreted in the restrictive terms of the transmission of competences. It is not only a matter of what kind of competences or 'knowledge' are required in the digital age, but of the ideals or 'ethics' associated with its present and future. In this perspective, as I argued elsewhere (Stocchetti, 2017a), the effective challenge to the capitalist appropriation of digital technology requires the formation of individuals or personae willing and able to engage in the social construction of reality as a dialectical process and in support of emancipative values.

The introduction of media literacy in media education curricula falls dramatically short of this goal. What is needed, instead, is a more radical approach to media education that I would like to refer to here as critical media literacy.

Media literacy is obviously not enough if this notion is interpreted as the mere acquisition of competences that are supposedly necessary for the participation of the individual in the media and information order of digital capitalism. Learning to use digital media is important and it appears as difficult today as learning to read and write must have appeared difficult to most in the $16^{\text {th }}$ century. That alone, however, is not enough because the formation of digital subjectivities combines with capitalist interpellation and, given ideological control of technological development, the process of socialization in the digital age participates in the socialization of the capitalist social order. If the goal is to challenge the capitalist appropriation of technological development and oppose the injustices associated with it, media education should engage with ideological interpellation and the legitimization of power relations.

Unfortunately, even in most authoritative and perhaps influential expressions as, for example, the draft version of the Paris Declaration on Media and Information Literacy in the Digital Age ${ }^{1}$, media literacy is construed as the acquisition of competence that, while inspired by laudable values, seems to ignore actual power relations (e.g. corporate power) and the possibility of futures radically different from the present.

Critical media literacy is the term for an approach to media education that is in many respects still a work in progress and, although useful formulations are available (e.g., Kellner \& Share, 2007; Hammer, 2011; Mason, 2016; Nam, 2010), is still underdeveloped.

Media literacy puts the emphasis on the capacity to use available technology but

1 http://www.unesco.org/new/fileadmin/MULTIMEDIA/HQ/CI/CI/pdf/news/paris mil declaration.pdf 
do not problematizes the ideological dimension and the legitimation of relations of power. In this approach, 'critical' competence is a generic capacity to have an opinion and make rational choices. In critical media literacy instead, the core competence is to identify the nature of the forces that seek to influence our choices and the grounds on which these forces justify their influence. Inherent in this notion is the idea that, in order to bring about the 'subversion' sought by Feenberg, media education, and perhaps formal education in general, can be usefully inspired by the critical pedagogy of Paulo Freire and others.

A core goal of this pedagogy is critical consciousness, and the possibility to enable learners to identify relations of power and to assess their legitimacy, or the grounds of their justification (Freire, 1974/2013; Freire, 1998/2001). Applied to critical media literacy, this goal consists in the capacity to engage with media in problematizing the role of ideological interpellation, digital technology and the media themselves within the broader context of the social construction of reality and the tensions I have here discussed in the terms of the dialectics of the real.

More precisely, the capacity to assess the nature of power relations, the grounds for their legitimacy, is a pre-requisite to the choice of compliance or resistance, which are in essence moral choices. In relation to the invisibilities of the digital age, critical media literacy consists in the acquisition of the capacity to identify and assess the nature and especially the legitimacy of the power relations associated with the digitalization of society. This competence is key to recognizing invisibilities and to distinguishing those that are constitutive of injustice from those who merely represent difference. From this perspective, the critical theory of technology is an important element in the formation of the critical media literacy curriculum, especially for educators. In other words, where media literacy is inspired by a pedagogical model that seeks individual 'adaptation', critical media literacy pursue the ideal of 'integration'. The difference, as Freire put it, is crucial:

Integration with one's context, as distinguished from adaptation, is a distinctively human activity. Integration results from the capacity to adapt oneself to reality plus the critical capacity to make choices and to transform reality. To the extent that man loses his ability to make choices and is subjected to the choices of others, to the extent that his decisions are no longer his own because they result from external prescriptions, he is no longer integrated. Rather, he has adapted. He has "adjusted". Unpliant men, with a revolutionary spirit, are often 
termed "maladjusted". The integrated person is person as Subject. In contrast, the adaptive person is person as object, adaptation representing at most a weak form of self-defence. If man is incapable of changing reality, he adjusts himself instead. Adaptation is behaviour characteristic of the animal sphere; exhibited by man, it is symptomatic of his dehumanization. Throughout history men have attempted to overcome the factors which make them accommodate or adjust, in a struggle - constantly threatened by suppression - to attain their full humanity. (Freire, 1974/2013, p. 4) (Italics in the original)

Thus, the re-politicization of the social construction of reality requires that formal education provides critical media literacy, instead of mere media literacy, because the problem is not merely one of learning to use to the digital media but of subverting the illegitimate relations of power that capitalist digitalization seeks to hide and naturalize. Actual emancipation requires individuals to effectively engage and oppose the influence of capitalist interpellation on digital technology - in other words, refusing to be 'prosumers' and instead enforcing their rights as citizens.

\section{REFERENCES}

Allmer, T. (2015). Critical theory and social media: between emancipation and commodification. London: Routledge.

Althusser, L. (2008). On Ideology. London: Verso. (Original work published 1971)

Barthes, R. (2000). Mythologies. London: Vintage. trans Annette Lavers. (Original work published 1957)

Carey, J. W. (1988). Communication as Culture. Essays on Media and Society. Boston: Unwin Hyman.

Cover, R. (2016). Digital Indentities. Creating and Communicating the Online Self. London: Elsevier.

Dahlberg, L. (2011). Re-constructing digital democracy. New Media \& Society, 13(6), pp. 855-872.

Duff, A. S. (2012). A Normative Theory of the Information Society. London: Routledge. 
Feenberg, A. (1992). Subversive Rationalization: Technology, Power, and Democracy. Inquiry, 35(3/4), pp. 301-22.

Feenberg, A. (2009). Critical Theory of Technology. In: A Companion to the Philosophy of Technology. s.l.:Blackwell, pp. 146-153.

Ferneding, K. A. (2003). Questioning Technology. Electronic Technologies and Educational Reform. New York: Peter Lang.

Fisher, E. (2010). Contemporary Technology Discourse and the Legitimation of Capitalism. European Journal of Social Theory, 13(2), p. 229-252.

Flaxman, S., Goel, S., \& Rao, J. M. (2016). Filter Bubbles, Echo Chambers, and Online News Consumption. 80. Public Opinion Quarterly, 80(Special issue), pp. 298320 .

Freire, P. (2001/1998). Pedagogy of Freedom: Ethics, Democracy, and Civic Courage. Lanham: Rowman \& Littlefield.

Freire, P. (2013). Education For Critical Consciousness. London: Bloomsbury. (Original work published 1974)

Fuchs, C. (2014). Social Media: A Critical Introduction. London: Sage.

Hammer, R. (2011). Critical Media Literacy as Engaged Pedagogy. E-Learning and Digital Media, 8(4), pp. 357-363.

Hardy, J. (2014). Critical Political Economy of the Media. Oxon: Routledge.

Hassan, R. (2003). Network Time and the New Knowledge Epoch. Time \& Society Vol. 12, 2/3, pp. 225-241.

Horkheimer, M. (2004). The Eclipse of Reason. London: Continuum. (Original work published 1947)

Horkheimer, M., \& Adorno, T. W. (2002). Dialectic of Enlightenment. Philosophical Fragments. Stanford Stanford University Press. (Original work published 1969)

Inayatullah, S. (1998). Deconstructing the Information Era. Futures, 30(2), pp. 235-47.

Kellner, D., \& Share, J. (2007). Critical media literacy is not an option. Learning Inquiry, 1(1), pp. 59-69. 
Lasswell, H. D. (1950). Politics. Who Gets What, When, How. New York: Peter Smith. (Original work published 1936)

Lyotard, J.-F. (1982). The Postmodern Condition: A Report on Knowledge.. Minneapolis:: University of Minnesota Press. (Original work published 1979)

Machlup, F. B. (1962). The Production and Distribution of Knowledge in the US. Princeton: Princeton University Press.

Machlup, F. B. (1980-84). Knowledge: Its Creation, Distribution and Economic Significance. 4 volumes. Princeton: Princeton University Press.

Marcuse, H. (1998). Some implications of modern technology. In: Technology, war, and fascism. London: Routledge. (Original work published 1941)

Marcuse, H. (2002/1964). One-Dimensional Man. Studies in the Ideology of Advanced Industrial Society. London: Routledge.

Mason, L. (2016). McLuhan's challenge to critical media literacy: The City as Classroom textbook. Curriculum Inquiry, 46(1), pp. 79-97.

Masuda, Y. (1981). The Information Society as Post-industrial Society (ed. or. 1980, Institute for the information society, Tokyo). Washington: World Future Society.

Mosco, V. (2004). The Digital Sublime. Myth, Power, and Cyberspace. Cambridge: The MIT Press .

Nam, S. (2010). Critical Media Literacy as Curricular Praxis Remapping the Pedagogical Borderlands of Media Literacy in U.S. Mass Communication Programmes. Javnost-The Public. Journal of the European Institute for Communication and Culture, 17(4), pp. 5-23.

Pariser, E. (2011). The Filter Bubble: How the New Personalized Web Is Changing What We Read and How We Think. New york: Penguin.

Polanyi, K. (2001). The Great Transformation. The Political and Economic Origins of Our Time. Boston: Beacon Press. (Original work published 1944)

Rooksby, E., \& Weckert, J. (eds.) (2007). Information Technology and Social Justice. Hershey: Idea Group. 
Rushkoff, D. (2010). Program Or Be Programmed. Ten Commands For a Digital Age. na: $\mathrm{O} / \mathrm{R}$.

Schiller, H. I. (1980). Whose New International Economic and Information Order?. Communication, 5(4), pp. 299-314.

Schiller, H. I. (1981). Who knows: Information in the Age of the Fortune 500. New York: Prager.

Shiller, D. (1999). Digital Capitalism: Networking the Global Market System. Cambridge: MIT press.

Stocchetti, M. (2014). Images and Power in the Digital Age: The Political Role of Digital Visuality. KOME. An International Journal of Pure Communication Inquiry, 2(2), pp. 1-16.

Stocchetti, M. (2017a). Persona and parrhesia: research notes on the dialectics of the real. Persona Studies, 3(1), p. n.a..

Stocchetti, M. (2017). Re-making the Truth in the Digital Age. Parrhesia and Human Interest. Comunicazioni sociali, Issue 3, pp. 405-414.

van DijK, A. G. M. (2012). The Evolution of the Digital Divide. The Digital Divide Turns to Inequality of Skills and Usage. In: J. e. a. Bus, ed. Digital Enlightenment Yearbook 2012. Amsterdam: IOS Press, pp. 57-75. 